INSIGHTS INTO REGIONAL DEVELOPMENT

ISSN 2669-0195 (online) http://jssidoi.org/IRD/ 2019 Volume 1 Number 3 (September) http://doi.org/10.9770/IRD.2019.1.3(6)

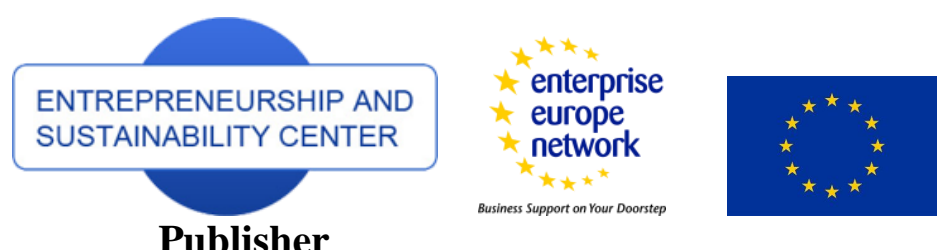

http://jssidoi.org/esc/home

\title{
TOWARDS ENERGY EFFICIENCY: CASE OF MOROCCO*
}

\section{Lahcen El Iysaouy ${ }^{1}$, Najiba El Amrani El Idrissi ${ }^{2}$, Manuela Tvaronavičiené ${ }^{3}$, Mhammed Lahbabi ${ }^{4}$, Abdelmajid Oumnad ${ }^{5}$}

${ }^{1,5}$ Equipe de Recherche en Smart Communications - ERSC (ancien LEC)

Ecole Mohammadia d'Ingénieurs, Mohammed V University in Rabat

Avenue Ibn Sina BP765 Agdal, Rabat, Morocco

1, 2, ${ }^{4}$ Universite Sidi Mohamed Ben Abdellah, FSTF, LSSC,

B.P. 2202, Route d'Immouzzer, Fés, Marocco

${ }^{3}$ Vilnius Gediminas Technical University, Sauletekio al. 11, Vilnius, Lithuania

E-mails: ${ }^{1}$ lahcen.eliysaou@um5s.net.ma; ${ }^{2}$ najiba.elamrani@usmba.ac.ma ; ${ }^{3}$ manuela.tvaronaviciene@vgtu.lt ,

4hhammed.lahbabi@usmba.ac.ma; ${ }^{5}$ aoumnad@emi.ac.ma

Received 15 May 2019; accepted 30 June 2019; published 30 September 2019

\begin{abstract}
A major challenge for humanity in the twenty-first century is to combine energy with respect for the environment. During the Rio Earth Summit (2012) the issue of sustainable development was clearly demonstrated. One of the major battles this century for the planet's survival is to include energy efficiency as an international policy priority in order to achieve a significant decrease in greenhouse gas emissions. In this paper, we have presented the current state and outlook of energy efficiency in the transport, residential and industrial sectors, as well as its policy for each sector in Morocco. New strategies implemented by the government for sustainable development were reviewed and discussed. Through these strategies, the shift to energy efficiency is at the forefront of national policy implications for energy security and a low-carbon economy.
\end{abstract}

Keywords: energy efficiency; low-carbon; energy policy; energy consumption; ggreenhouse gases; Morocco

*This research was supported by the projects, which have received funding from the European Union: International Research Staff Exchange Scheme (IRSES) FP7-PEOPLE-2012-IRSES, Grant Agreement Number 319017 SHuMED and ES H2020MSCA-RISE-2014 CLUSDEVMED Grant Agreement Number 645730730

This work is in principle linked to the project "Energy Efficiency: Cultural Change" finaced by NATO Energy Security Centre of Excellence
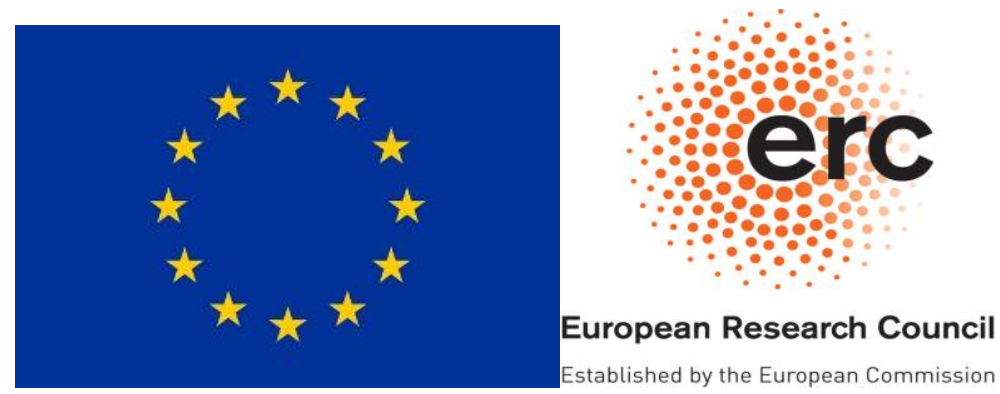


\section{INSIGHTS INTO REGIONAL DEVELOPMENT}

ISSN 2669-0195 (online) http://jssidoi.org/jesi/

2019 Volume 1 Number 2 (September)

http://doi.org/10.9770/IRD.2019.1.3(6)

Reference to this paper should be made as follows: El Iysaouy, L.; El Amrani El Idrissi, N.; Tvaronavičienė, M.; Lahbabi, M.; Oumnad, A.

2019. Towards energy efficiency: case of Morocco, Insights into Regional Development 1(3): 259-271. https://doi.org/10.9770/ird.2019.1.3(6)

JEL Classifications: Q4, Q5

\section{Introduction}

World demand for energy is increasing through population increase, as well as through industrialization and the urban development process (Energy, Photovoltaic, System, Iea, \& Publishes, 2018; IEA, 2017). This underscores the value of such issues such as sustainability, supply security, alternative forms of energy and the strengthening of the national energy source potential. The latest evolutions and trends, the sharp swells in demand, warfare, and diplomatic concerns all contribute to the perception of energy issues as a serious issue on the world's agenda. In some references, energy efficiency is among the energy resources. Rather than starting to build a new plant with high-cost investments, the energy efficiency of the plant can contribute towards meeting the growing need for energy. In addition, it could deliver significant environmental and other operational rewards in terms of cost and greenhouse gas emissions improvements.

Energy efficiency policies are used in various sectors (i.e. residential, industry, transport, etc.) (Allouhi et al., 2015; Kousksou et al., 2015; T. T. Xu, 2011, Tvaronavičienè et al., 2017 Tvaronavičienė, 2018; Dudin et al., 2019; Vlasov et al., 2019; Smaliukiené, Monni, 2019; Rogalev et al., 2018).

By virtue of its status as a developing country, Morocco is considered among the 75 most competitive countries in the world, and among the 140 countries ranked in the 2018 World Competitiveness Report released by the World Economic Forum. The average level of competitiveness in Morocco was 72.17 in the period 2007-2018, reaching an unprecedented high of 77 in 2014 and a peak of 64 in 2008 ("Morocco GDP Growth Rate | 2019 | Data | Chart | Calendar | Forecast | News," n.d.).

Morocco's annual Gross domestic product (GDP) was growing at an average rate of $4.14 \%$ from 1999 to 2018 , reaching an unprecedented high of $9.30 \%$ in the second quarter of 2006 and a record low of $0.50 \%$ in the fourth quarter of 1999 ("Morocco GDP Growth Rate | 2019 | Data | Chart | Calendar | Forecast | News," n.d.).

To meet the high demand for electricity which is increased by about 7\%., Morocco intends to invest more than 15 billion euros over the next 10 years to increase installed capacity by around 6,750 MW.

The most important measure in Morocco's energy balance is the total consumption of 28.25 billion kWh of electricity per year. This represents an average of $790 \mathrm{kWh}$ per capita. However, Morocco could supply itself completely with self-produced energy. Whereas, the total production of all electricity generation facilities is 29 billion $\mathrm{kWh}$. In addition to pure consumption, production, imports, and exports have an important contribution to make other energy sources such as natural gas or crude oil are used as well. A large amount of electricity used contributes to high levels of $\mathrm{CO}_{2}$ emissions in Morocco. On the other hand, energy intensity aimed to be decreased by enhancing efficiency measures and promoting clean energy technologies (Iea, 2019).

Energy efficiency in the transport sector in Morocco deserves attention from the point of view of energy security and the environment, as the sector depends almost exclusively on a fuel-oil which represented the lion's share of the energy imported. 


\section{INSIGHTS INTO REGIONAL DEVELOPMENT}

ISSN 2669-0195 (online) http://jssidoi.org/jesi/

2019 Volume 1 Number 2 (September)

http://doi.org/10.9770/IRD.2019.1.3(6)

The transport is the key factor of global sustainable economic development as reported issued in International Transport Forum (ITF) Transport Outlook 2013 based relatively cost-efficient as well as reliably networked transport. However, the transport sector is responsible for air pollution, because it causes large greenhouse gases emissions into the atmosphere, which eventually leads to climate change. Therefore, the main task for policy makers struggling to elaborate on strategic transport plans is to a trade-off between the pros and cons of transport developments.

Such strategic planning for the long term is only feasible if there is factual and reliable information on transport development which is based on statistics, analysis, and research.

The industrial sector represents between 30 and $70 \%$ of the world's total energy use and is responsible for a significant proportion of global greenhouse gas emissions (Broberg Viklund \& Johansson, 2014; T. T. Xu, 2011). There have been recent researches that have investigated the potential to reduce greenhouse gas emissions by enhancing industrial energy efficiency (Utlu \& Parali, 2013; Worrell, Blinde, Neelis, Blomen, \& Masanet, 2010; T. Xu, Sathaye, \& Kramer, 2013).

Improving energy efficiency in the industrial sector is one of the major pillars of this strategy. Further, intends to require energy audits in the industry sector to achieve the targeted energy efficiency ratio (from 12 to $15 \%$ ) by 2020. The obligation of energy audits in industries is clearly stated in the 12th article of the Energy Efficiency Law 47-09 (Law, n.d.).

To energy efficiency policies in the area of transport, residential, and industry there are certain theories which should be considered such as the theory of rational choice, the theory of reasoned action, the theory of planned action, the theory of social learning, the theory of cognitive dissonance, and social theory, etc. Further, various energy efficiency surveys in industrials, residentials, transports sectors are exploring energy consumption patterns. The methodology employed in these studies is to interview holds of different sectors such as households to identify their electricity use patterns and understanding the values that are driving their behaviours. The use of questionnaires to outline the efforts of both consumers and government bodies on energy concerns (Dianshu, Sovacool, \& Vu, 2010; Whitmarsh \& O'Neill, 2010). Also, there are studies suggesting that may be more effective economic concerns rather than environmental concerns (Gyamfi \& Krumdieck, 2011).

There are a lot of energy reduction policies pursued in many countries. Increasing the acquaintance, offering feedback, incentives, disincentives, and social influences are among the examples of behaviour change measures used in policy-making.

These actions are outlined in the following:

- Public information: Positive information interventions enhance the level of awareness and knowledge of the energy concerns of the individuals. To disseminate the information that there are several ways among the people: workshops, flyers/posters, mass-media campaigns, home-based audits, energy labelling and modelling (Abrahamse, Steg, Vlek, \& Rothengatter, 2005; Robinson, 2009).

- Feedback: To keep people informed of their use, it is possible to provide feedback under different forms and at different frequencies. The most common form of feedback for electricity users is utility bills. (Abrahamse et al., 2005; Nachreiner, Mack, Matthies, \& Tampe-Mai, 2015).

- Incentives / benefits: Both monetary and non-monetary rewards can motivate people to save energy. These can result from a reduction in energy use or a more successful change in energy efficiency behaviour (Abrahamse \& Steg, 2009; Bresciani, Colorni, Lia, Luè, \& Nocerino, 2016; McMakin \& Malone, 2002).

- Target setting / Investment: This is an alternative approach to motivate people to become involved to save energy. An engagement is an oral or written commitment or pledge of change, and it may be linked to an 


\section{INSIGHTS INTO REGIONAL DEVELOPMENT}

ISSN 2669-0195 (online) http://jssidoi.org/jesi/

2019 Volume 1 Number 2 (September)

http://doi.org/10.9770/IRD.2019.1.3(6)

objective. This guarantee can be a bond for oneself, in which case it can be used to activate either of the following a personnal norm such a high moral obligation to conserve the energy (Abrahamse \& Steg, 2009; Martiskainen, n.d.).

- Social influences: These kinds of measures of attitude and behaviour are taken from a larger group of people than the previous ones. Group or organization leading people to achieve a common purpose or even sometimes to challenge each other between themselves to get the greatest possible reduction in their energy use. (Abrahamse \& Steg, 2009).

Through the years, researches have been carried out to foster policies and to study the impact of implementing strategies on energy reduction and efficiency. The full range of literature and the common policy alternatives derived from the literature are not restricted to those outlined above. In recent literature, it has been highlighted again that a more effective combination of awareness and education with cost-effective measures is more efficient (Lindén, Carlsson-Kanyama, \& Eriksson, 2006) and shows that the economic rewards of energy saving as a result of these activities increase consumer awareness levels. Through the different studies, the common conclusion was that holds of different sectors were responding to these economic measures and that they needed to be used effectively to achieve energy efficiency (Allcott, 2011).

\section{Energy intensity of Morocco}

In 2017, the total final consumption (TFC) of Morocco reached 16.1 Mtoe, which represents an increase of 34\% over the previous decade (AZEROUAL, EL MAKRINI, EL MOUSSAOUI, \& EL MARKHI, 2018; Iea, 2019). The TFC is widely driven by the three sectors - transport, residential and industrial - as well as representing over four-fifths of the total final consumption, but also exhibiting high expansion and growth rates. Despite the energy consumption of Morocco increases along with the economic development of the country, however, as compared to a decade ago, energy intensity (TFC / GDP) fell by 9\% (see Figure 1). In terms of energy intensity, which is measured by the ratio of TFC per unit of real gross domestic product as settled for purchasing power parity (PPP), it was 60.5 tonnes of oil equivalents (toe) per million dollars of GDP in 2017.

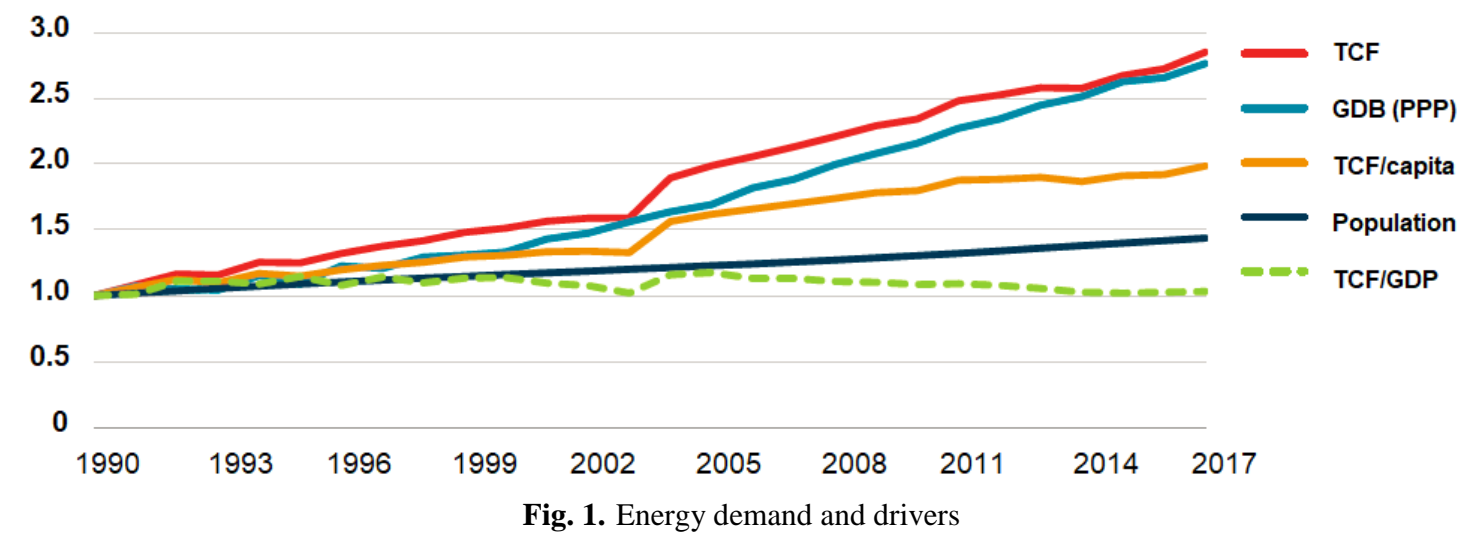

Source: IEA (2019 forthcoming), World Energy Balances 2019 preliminary edition, www.iea.org/statistics/

The energy intensity of Morocco has diminished over time ( see Figure 2) as well as, within the Mediterranean area, its energy use profile is unique. 


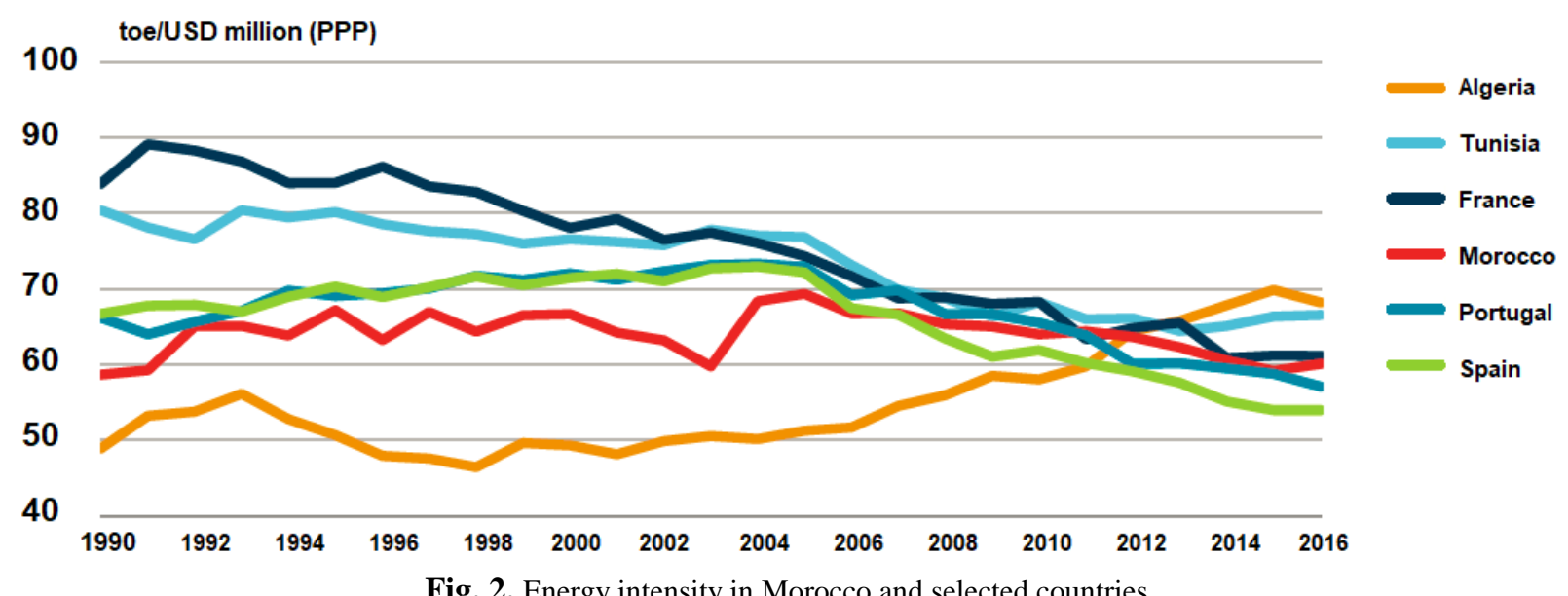

Fig. 2. Energy intensity in Morocco and selected countries

Source: IEA (2018a), World Energy Balances, 2018, www.iea.org/statistics/

\section{Energy Efficiency in the Transport sector}

\subsection{Energy consumption}

The transport sector used 5.8 Mtoe in 2017, representing the highest proportion of Moroccan TFC. Energy use in transport has increased by 58\% since 2007 and increased more than four times since 1990 (AZEROUAL et al., 2018; Iea, 2019). Petroleum is the most dominant transport fuel in Morocco's rapidly expanding transport sector, while electricity and biofuels have no role to play.

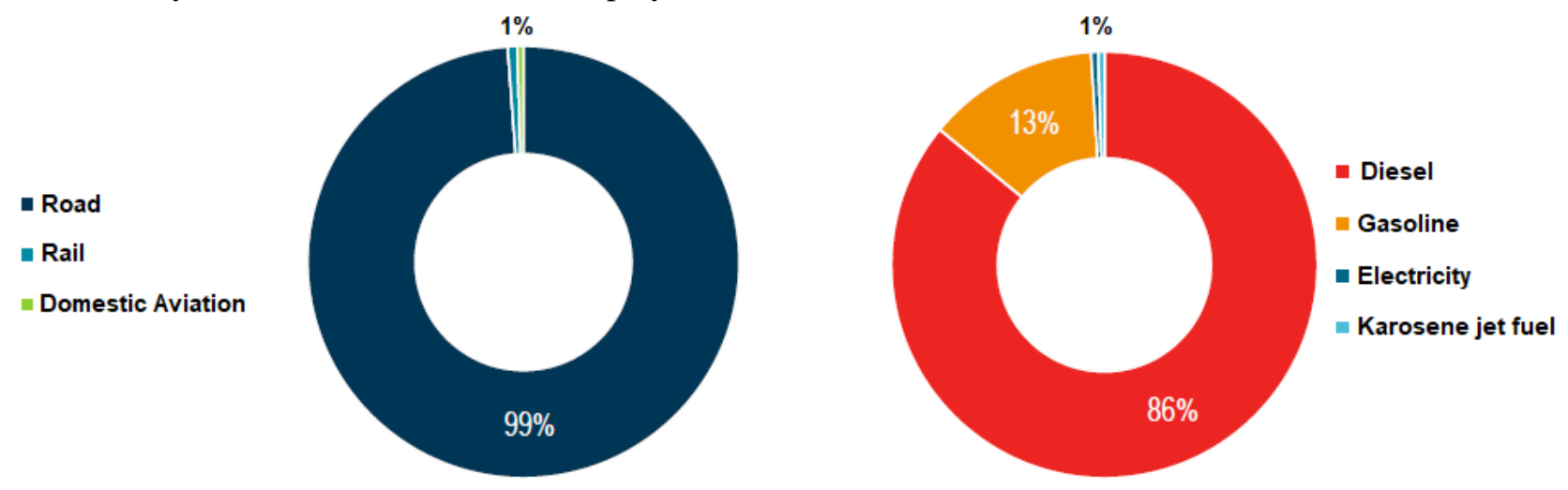

Fig. 3.Transport energy demand by transport mode and fuels, 2017

Source: IEA (2019 forthcoming), World Energy Balances 2019 preliminary edition www.iea.org/statistics/

Highway transport uses $99 \%$ of transport energy, with about $86 \%$ of this consumption being from diesel and the remaining from gasoline ( see Figure 3). Transport use in Morocco is mainly driven by freight, passenger cars, cabs, and commercial vans. The constant growth in the overall vehicle fleet reflects Morocco's GDP per capita growth of the country's government, and its aspiration to be a regional pole of the automotive industry. 


\subsection{Various policy targets in transport sector}

Measures for energy efficiency in the transport sector have been enacted in various strategies (Iea, 2019; Law, n.d.):

- The strategy of the Ministry of Equipment, Transport, Logistics and Water (METLW) for 2017-2021 highlights the importance of sustainability, economic and socially efficient transport systems, which are more reliable, more energy efficient to use more user-friendly.

- Strategy for developing the competitiveness of Moroccan logistics is intended to decrease the use of energy by 2030, as well as to foster multimodal transportation and the transition to more efficient modes of transport.

Also, several measures have already been taken in place in road transport to reduce greenhouse gas emissions in a significant way (METLW,2018). Moreover, developing a national roadmap for sustainable mobility supported by the German Development Institutions (GIZ).

\section{Energy Efficiency in the residential sector}

\subsection{Energy consumption}

The residential sector has consumed 4.0 Mtoe in 2017, which represents a $26 \%$ increase compared to 2007. The oil, essentially liquefied petroleum gas (LPG), is the main fuel used by $63 \%$ of total consumption in the industry, followed by electricity (23\%), and biofuels (14\%) (Figure 4.7) (AZEROUAL et al., 2018; Haas, 1997; Lebied, Sick, Choulli, \& El Bouardi, 2018). During the period 2007-2017, the use of LPG increased by 50\% and electricity by $67 \%$, which replaced the solid biofuels that had been the primary source of heating and cooking. In the residential sector, the uptake of traditional types of biomass-wood and charcoal dropped to $43 \%$ over the same period. This is reflective of the efforts made by the Moroccan government to develop alternatives to biomass, in order to avoid deforestation as well as the health problems that are related to their use.

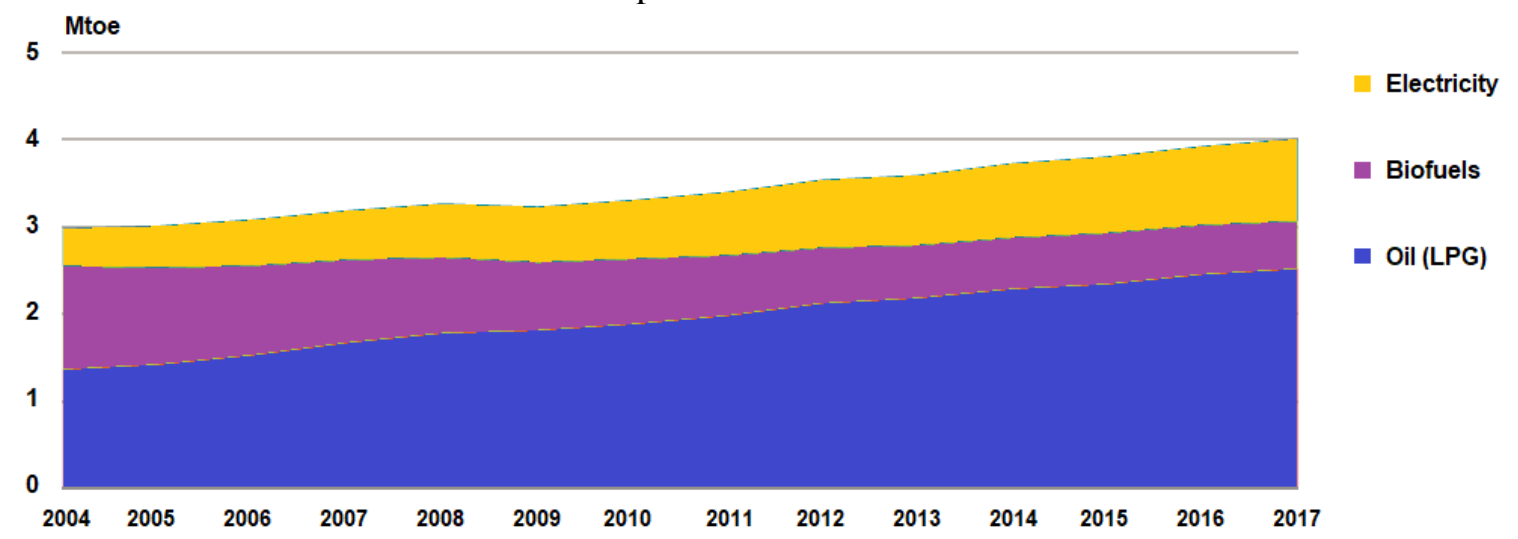

Fig. 4 TFC in residential sector by source

Source: IEA (2019 forthcoming), World Energy Balances 2019 preliminary edition www.iea.org/statistics/

Morocco's cooking represents roughly two thirds of the residential sector's total energy use. Other main residential energy needs include water heating, refrigeration, lighting and electrical appliances. Heating and cooling of space account for a very small part of total household energy consumption, such as shown in Figure 4. 
Meanwhile, residential energy use rose by $27 \%$ over the period 2006 to 16 in parallel with demographic growth, the energy use by building sector slightly declined over the period, reflecting the turnover of the building fleet with new and more energy efficient dwellings (see Figure 5).

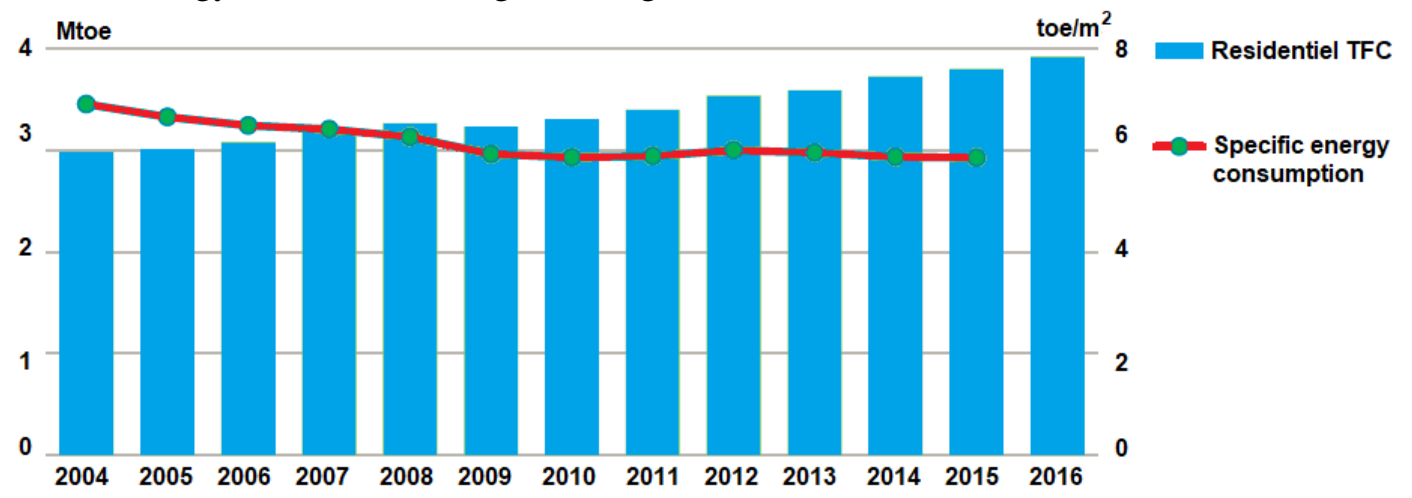

Fig. 5. Residential consumption and energy intensity

Source: IEA (2018a), World Energy Balances, 2018, www.iea.org/statistics/

The consumption of oil is still representing about $63 \%$ of residential energy use in Morocco. Morocco has reached the universal access to electricity on the part of its rural population, which promotes an increasing and widespread use of electricity as well as the use of modern appliances, especially to meet cooling and other needs.

\subsection{Various policy targets in residential sector}

The main laws that govern this sector of residential are (Iea, 2019; Law, n.d.):

Law No. 47-09 on the energy efficiency of 17 November 2011:

- Requiring the company to provide information on power capacity and the use of energy, as well as to carry out mandatory energy audits if the use exceeds 500 toe (oil equivalent) tonnes per year.

- Implementation of the standard NM 14.2.300 on the labeling of household appliances and electrical products. The appliances that require mandatory labeling are cooling appliances (refrigerators, freezers and air conditioners), cooking appliances (electric ovens), cleaning appliances (dishwashers, washing machines and dryers).

- Increasing the public awareness initiatives to promote the transition to more efficient appliances as well as to provide the benefits of using appliances with higher efficiency standards to the public.

- Implementation of summer time, by adopting the GMT+1 time zone during the summer months (MayJuly, September-October) to improve the use of daylight.

On the other hand, there are plans to:

- Renovation of the city's public lighting installations.

- Extension of the public lighting network to the entire urban territory.

- Reduce the impact of energy costs on the municipal budget (consumption and maintenance).

- Establish a preventive and corrective maintenance regime to ensure that equipment is maintained in optimal technical and economic conditions.

the implementation of the Law No. 47-09 on the energy efficiency is estimated in the side of labeling to save a net of $8 \%$ of national electricity consumed within 15 to 20 years. Further, the implementation of energy efficiency law will reduce the emissions of greenhouse gaze. 


\title{
5. Energie effiency in the industrial sector
}

\subsection{Energy consumption}

The major energy sources used in Morocco are oil and electricity (see Figure 6). Fuel oil or other petroleum products are by far the most significant energy source, representing $68 \%$ of overall use in 2017, while electricity is the second most important source, $3 \%$ biofuels and waste as well as $2 \%$ of natural gas. The TFCs in the industry reached 3.8 Mtoe in 2017, up from the peak reached during 2011-13 (AZEROUAL et al., 2018; Iea, 2019). The use of oil decreased from 2013 onwards as subsidies for fossil fuels were abolished and subsequently increased again in 2017.

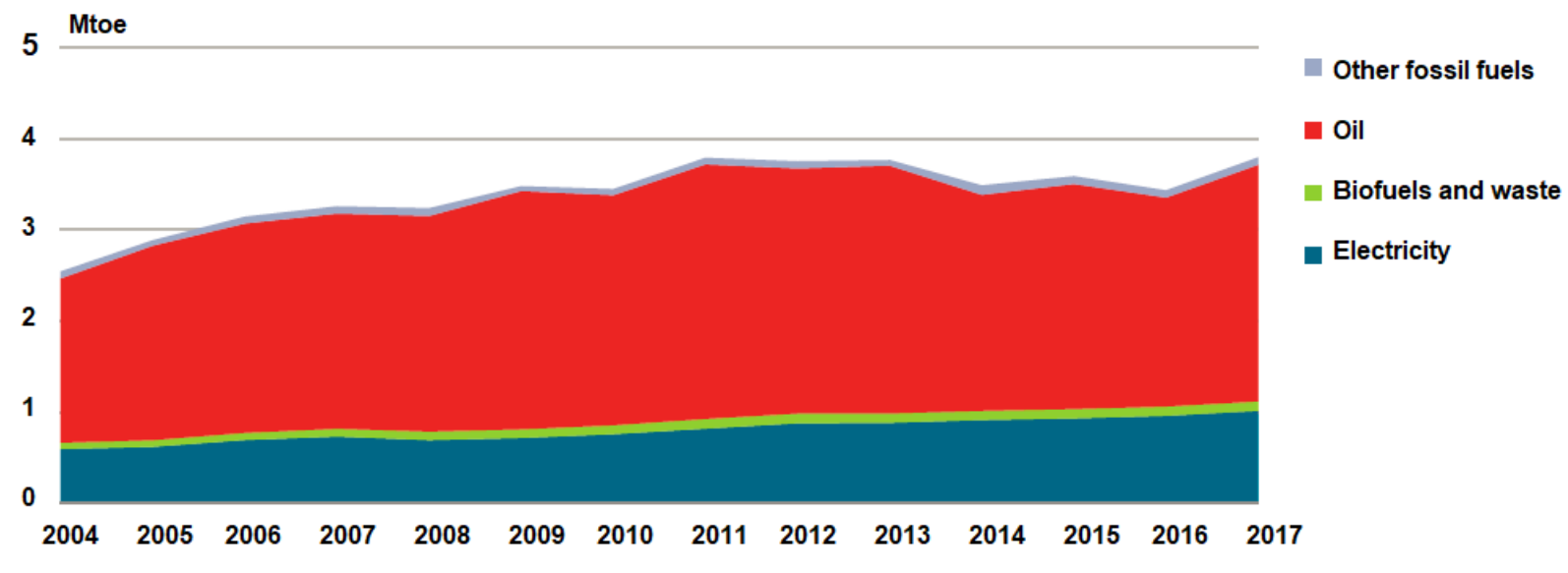

Fig. 6 TFC in the industry by source

Source: IEA (2019 forthcoming), World Energy Balances 2019 preliminary edition, www.iea.org/statistics/

The non-metallic minerals industry and the mining and quarrying industries are the two most important industries regarding the use of energy, representing about $60 \%$ of the sector's total use. However, the cement industry (Lafarge, Ciments of Morocco) is the only responsible for a third of total industry use. The extraction and chemical process of phosphate rocks in Morocco covers more than $20 \%$ of industrial energy consumption and represents $50 \%$ of total GDP.

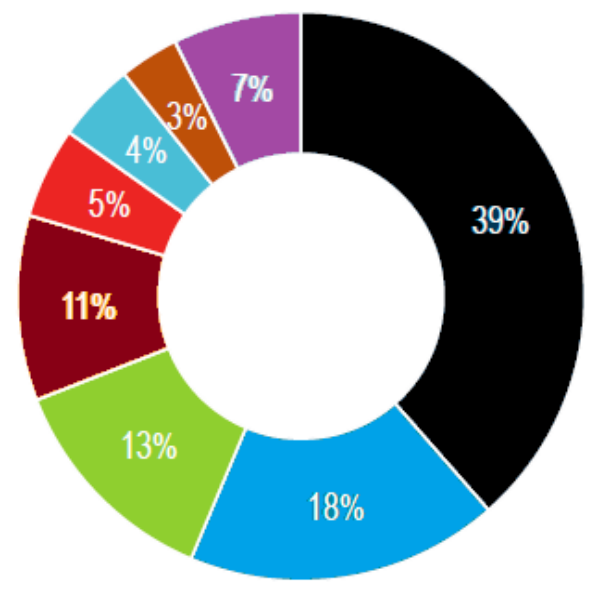

\author{
- Non-metallic minerals \\ - Mining and quarrying \\ - Non-energy use in industry \\ - Food and tobacco \\ - Non-ferrous metals \\ n Chemicals and petrochemical \\ - Textile and leather \\ - Other
}

Fig. 7. TFC in industry by sector, 2016

Source: IEA (2019 forthcoming), World Energy Balances 2019 preliminary edition, www.iea.org/statistics/ 
The production of chemicals involves the processing of phosphate into fertilizers and other chemicals. The remaining industrial sectors, which include the processing industries, such as pulp and paper, food products (i.e sugar production) and tobacco processing, textile, and leather production (Figure 6).

Despite the fact that industrial energy use rose by $41 \%$ in 2004-2015, its intensity declined during the same period by $13 \%$. A decrease in energy use intensity per unit of GDP is mainly due to more energy efficient industrial processes or to structural changes in the national industry.

\subsection{Various policy targets in commercial sector}

The main laws that govern this sector of commercial are (Iea, 2019; Law, n.d.): Law No. 47-09 on energy efficiency in the industrial sector:

- Requiring companies to declare their installed capacity and energy use, as well as to carry out mandatory energy audits, if the use exceeded 1500 tons of oil equivalent (toe) per year.

- Training sessions to assist companies of large scale business in the process of optimization and streamline their use.

- Shifting the energy use of Morocco's industrial sector from the super peak tariff in order to benefit from a significantly lower rate in hours of low demand. For instance, the companies of high energy-intensive companies, including the steel industries, have been joining this program of energy efficiency to decrease their energy bills.

- Morocco's industrial sector is very sensitive to peak electricity prices. The super peak tariff for industries prompts them to shift their energy use out of the peak periods on a voluntary basis, in order to benefit from a significantly lower rate in hours of low demand. Further, several energy-intensive companies, including the steel industries, have been joining this program of energy efficiency to decrease their energy bills.

- Encouragement of the companies to become more energy efficient by setting limits on air pollutant emissions. Further, improvements in energy efficiency, meanwhile, reduce Greenhouse gases emissions.

\section{Conclusions}

The high levels of energy demand resulting from socio-economic development are the key concerns of the 21st century world. In fact, policy makers around the world are pursuing suitable innovative strategies to reach sustainable development, in which enhancing the life-quality and protecting the environment are high priorities.

The national energy strategy in Morocco, focusing on improving energy efficiency, is surely the most important national concern. It makes Morocco one of the most ambitious countries in the world in terms of promoting sustainable development. Consequently, Morocco has been the centre of significant investments in energy efficiency, mainly as a result of the high availability of energy resources.

In this paper, we reported the energy efficiency in Morocco in sectors of transport, residential, and industrial and emphasized that the swift transition to energy efficiency constitutes the main challenge for the Moroccan government. Consequently, we have briefly reported the energy policy for different sector and their achievements in Morocco. 


\section{INSIGHTS INTO REGIONAL DEVELOPMENT}

ISSN 2669-0195 (online) http://jssidoi.org/jesi/

2019 Volume 1 Number 2 (September)

http://doi.org/10.9770/IRD.2019.1.3(6)

\section{References}

Abrahamse, W., \& Steg, L. (2009). How do socio-demographic and psychological factors relate to households' direct and indirect energy use and savings? Journal of Economic Psychology, 30(5), 711-720. https://doi.org/10.1016/j.joep.2009.05.006

Abrahamse, W., Steg, L., Vlek, C., \& Rothengatter, T. (2005). A review of intervention studies aimed at household energy conservation. Journal of Environmental Psychology, 25(3), 273-291. https://doi.org/10.1016/j.jenvp.2005.08.002

Allcott, H. (2011). Social norms and energy conservation. Journal of Public Economics, 95(9-10), 1082-1095.

https://doi.org/10.1016/j.jpubeco.2011.03.003

Allouhi, A., Jamil, A., Kousksou, T., El Rhafiki, T., Mourad, Y., \& Zeraouli, Y. (2015). Solar domestic heating water systems in Morocco: An energy analysis. Energy Conversion and Management, 92, 105-113. https://doi.org/10.1016/j.enconman.2014.12.055

AZEROUAL, M., EL MAKRINI, A., EL MOUSSAOUI, H., \& EL MARKHI, H. (2018). Renewable Energy Potential and Available Capacity for Wind and Solar Power in Morocco towards 2030. Journal of Engineering Science and Technology Review, 11(1), 189-198. https://doi.org/10.25103/jestr.111.23

Bresciani, C., Colorni, A., Lia, F., Luè, A., \& Nocerino, R. (2016). Behavioral change and social innovation through reward: an integrated engagement system for personal mobility, Urban Logistics and Housing Efficiency. In Transportation Research Procedia (Vol. 14, pp. 353361). https://doi.org/10.1016/j.trpro.2016.05.087

Broberg Viklund, S., \& Johansson, M. T. (2014). Technologies for utilization of industrial excess heat: Potentials for energy recovery and CO2 emission reduction. Energy Conversion and Management, 77, 369-379. https://doi.org/10.1016/j.enconman.2013.09.052

Dianshu, F., Sovacool, B. K., \& Vu, K. (2010). The barriers to energy efficiency in China: Assessing household electricity savings and consumer behavior in Liaoning Province. Energy Policy, 38(2), 1202-1209. https://doi.org/10.1016/j.enpol.2009.11.012

Dudin, M.N., Frolova, E.E., Protopopova, O.V., Andrey Alievich Mamedov, A.A., Odintsov, S.V. (2019). Study of innovative technologies in the energy industry: nontraditional and renewable energy sources. Entrepreneurship and Sustainability Issues, 6(4), $1704-1713$. http://doi.org/10.9770/jesi.2019.6.4(11)

Energy, I., Photovoltaic, A., System, P., Iea, P., \& Publishes, P. (2018). IEA International Energy Agency I MPLEMENTING A GREEMENT ON P HOTOVOLTAIC P OWER S YSTEMS, 32.

Gyamfi, S., \& Krumdieck, S. (2011). Price, environment and security: Exploring multi-modal motivation in voluntary residential peak demand response. Energy Policy, 39(5), 2993-3004. https://doi.org/10.1016/j.enpol.2011.03.012

Haas, R. (1997). Energy efficiency indicators in the residential sector What do we know and what has to be ensured?, 25, 789-802.

Iea, B. (2019). Morocco 2019. Retrieved from https://webstore.iea.org/energy-policies-beyond-iea-countries-morocco-2019

IEA. (2017). Energy Efficiency 2018- Analysis and outlooks to 2040. Market Report Series, 1-143. https://doi.org/10.1007/978-3-64241126-7

Kousksou, T., Allouhi, A., Belattar, M., Jamil, A., El Rhafiki, T., \& Zeraouli, Y. (2015). Morocco's strategy for energy security and lowcarbon growth. Energy, 84, 98-105. https://doi.org/10.1016/j.energy.2015.02.048

Law, 47-09. (n.d.). Relative à 1 ' efficacité énergétique. Retrieved from http://www.aderee.ma/index.php/fr/expertise/efficacite-energetique

Lebied, M., Sick, F., Choulli, Z., \& El Bouardi, A. (2018). Improving the passive building energy efficiency through numerical simulationA case study for Tetouan climate in northern of Morocco. Case Studies in Thermal Engineering, 11, 125-134.

https://doi.org/10.1016/J.CSITE.2018.01.007

Lindén, A.-L., Carlsson-Kanyama, A., \& Eriksson, B. (2006). Efficient and inefficient aspects of residential energy behaviour: What are the policy instruments for change? Energy Policy, 34(14), 1918-1927. https://doi.org/10.1016/j.enpol.2005.01.015 


\section{INSIGHTS INTO REGIONAL DEVELOPMENT}

ISSN 2669-0195 (online) http://jssidoi.org/jesi/ 2019 Volume 1 Number 2 (September) http://doi.org/10.9770/IRD.2019.1.3(6)

Martiskainen, M. (n.d.). No Title.

McMakin, A. H., \& Malone, E. L. (2002). Motivating residents to conserve energy without financial incentives. Environment and Behavior, 34(6), 848-863. https://doi.org/10.1177/001391602237252

Morocco GDP Growth Rate | 2019 | Data | Chart | Calendar | Forecast | News. (n.d.). Retrieved June 10, 2019, from https://tradingeconomics.com/morocco/gdp-growth

Nachreiner, M., Mack, B., Matthies, E., \& Tampe-Mai, K. (2015). An analysis of smart metering information systems: A psychological model of self-regulated behavioural change. Energy Research and Social Science, 9, 85-97. https://doi.org/10.1016/j.erss.2015.08.016

Robinson, S. (2009). No Title. Chang. Behav. Case Study, 22.

Rogalev, A., Komarov, I., Kindra, V., Zlyvk, O. (2018). Entrepreneurial assessment of sustainable development technologies for power energy sector. Enterpreneurship and Sustainability Issues, 6(1), 429-445. http://doi.org/10.9770/jesi.2018.6.1(26)

Smaliukienė, R., Monni, S. (2019). A step-by-step approach to social marketing in energy transition. Insights into Regional Development, 1(1), 19-32. https://doi.org/10.9770/ird.2019.1.1(2)

Tvaronavičienė, M., Nesterova, K., Kováčik, V. (2017). Energy security and long-term energy efficiency: case of selected counties. Journal of Security and Sustainability Issues, 7(2), 349-357. https://doi.org/10.9770/jssi.2017.7.2(14)

Tvaronavičienè, M. 2018. Towards sustainable and secure development: energy efficiency peculiarities in transport sector. Journal of Security and Sustainability Issues, 7(4), 719-725. https://doi.org/10.9770/jssi.2018.7.4(9)

Utlu, Z., \& Parali, U. (2013). Investigation of the potential of thermophotovoltaic heat recovery for the Turkish industrial sector. Energy Conversion and Management, 74, 308-322. https://doi.org/10.1016/j.enconman.2013.05.030

Vlasov, A.I., Shakhnov, V.A., Filin, S.S., Krivoshein, A.I. (2019). Sustainable energy systems in the digital economy: concept of smart machines. Entrepreneurship and Sustainability Issues, 6(4), 1975-1986. http://doi.org/10.9770/jesi.2019.6.4(30)

Whitmarsh, L., \& O’Neill, S. (2010). Green identity, green living? The role of pro-environmental self-identity in determining consistency across diverse pro-environmental behaviours. Journal of Environmental Psychology, 30(3), 305-314.

https://doi.org/10.1016/j.jenvp.2010.01.003

Worrell, E., Blinde, P., Neelis, M., Blomen, E., \& Masanet, E. (2010). Energy Efficiency Improvement and Cost Saving Opportunities for the U.S. Iron and Steel Industry. Energy Efficiency Improvement and Cost Saving Opportunities for the U.S. Iron and Steel Industry.

$\mathrm{Xu}, \mathrm{T}$. T. (2011). Development of bottom-up representation of industrial energy efficiency technologies in integrated assessment models for the iron and steel sector. Development of Bottom-up Representation of Industrial Energy Efficiency Technologies in Integrated Assessment Models for the Iron and Steel Sector.

Xu, T., Sathaye, J., \& Kramer, K. (2013). Sustainability options in pulp and paper making: Costs of conserved energy and carbon reduction in the US. Sustainable Cities and Society, 8, 56-62. https://doi.org/10.1016/j.scs.2013.01.006 
INSIGHTS INTO REGIONAL DEVELOPMENT

ISSN 2669-0195 (online) http://jssidoi.org/jesi/ 2019 Volume 1 Number 2 (September) http://doi.org/10.9770/IRD.2019.1.3(6)

\section{Aknowledgements}

This research was supported by the projects, which have received funding from the European Union: International Research Staff Exchange Scheme (IRSES) FP7-PEOPLE-2012-IRSES, Grant Agreement Number 319017 SHuMED and ES H2020MSCA-RISE-2014 CLUSDEVMED Grant Agreement Number 645730730

This work is in principle linked to the project "Energy Efficiency: Cultural Change" finaced by NATO Energy Security Centre of Excellence

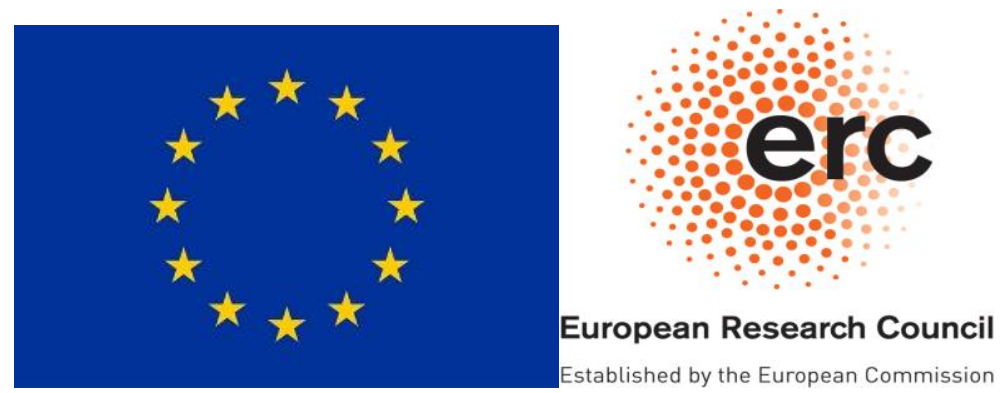

Lahcen EI IYSAOUY was born in Morocco, in 1989. He received the B.S. degree from Faculty of Sciences, Fez, Morocco in 2012 and M.S from Faculty of Sciences, Fez, Morocco in 2015. He is currently member of Electronic and Communication laboratory at Mohammadia School of Engineering -university mohammed v in Rabat -Morocco, and Signals, Systems and Components Laboratory at Faculty of Sciences and Technologies-University Sidi Mohamed Ben Abdellah -Fez, Morocco. His research interests include Power Electronics, Renewable Energy, Photovoltaics, Electrical Engineering, End Use of Photovoltaic Technology, Energy Efficiency, Energy Management.

ORCHID ID: https://orcid.org/0000-0001-9649-898X

Najiba EL AMRANI EL IDRISSI is Ph. D professor at the Electrical Engeniering Department, Faculty of Sciences and Technologies-

University Sidi Mohamed Ben Abdellah -Fez, Morocco. She's coordiuantor of the research team Signals, telecommunications and smart

grids of the Signals, Systems and Components Laboratory. She was graduated Engineer in Computer System and has a Ph.D. degree in

Electrical Engineering: Electro-technique and Power Electronics, from EMI (Mohammadia School of Engineering) Rabat, Morocco. She

has been:

- Program comity member of several international conferences.

- Head of Electrical Engineering department - FST- USMBA

- $\quad$ FP7 (7th Framework Programme for Research and Technological Development) ICT-National Contact Point of Morocco

- National Coordinator of several national and European projects FP6, FP7and Horizon 2020 (MAP-IT, ShuMED, ClusMED,

- IdealIst2011, MED-Dialogue, IdealIst 2014, ClusDevMED, FETUMA...)

- Chairman of the ETC's (ESCWA Technology Centre) technical commission 2013-2014

- Member of the Moroccan local team of Higher Education Reform Experts (HEREs); 2014-2018

Author ID: 56122394900 
INSIGHTS INTO REGIONAL DEVELOPMENT

ISSN 2669-0195 (online) http://jssidoi.org/jesi/

2019 Volume 1 Number 2 (September)

http://doi.org/10.9770/IRD.2019.1.3(6)

Manuela TVARONAVIČIENĖ is professor at Vilnius Gediminas Technical University of Lithunia. She is national head of European Union's Horizon 2020 research and innovation programme European Research Council (ERC) under the European Union's Horizon 2020 research and innovation programme Marie Sklodowska-Curie Research and Innovation Staff

Exchanges ES H2020-MSCARISE-2014 CLUSDEVMED (2015-2019) Grant Agreement Number 645730730.

ORCHID ID: http://orcid.org/0000-0002-9667-3730

Mhammed LAHBABI is professor in the Department of Electrical Engineering at Faculty of Sciences and TechnologiesUniversity Sidi Mohamed Ben Abdellah -Fez, Morocco. Received the state doctorate in optoelctronics from Faculty of Sciences and Technologies-University Sidi Mohamed Ben Abdellah -Fez, Morocco, in 2002. Received the research doctorate in physical science from University of Sciences and Techniques of Languedoc (Montpellier II) in 1990. He's Head of Signals, Systems and Components Laboratory.

Author ID: 56615430900

Abdelmajid OUMNAD is Professor in the Department of Electrical Engineering at Mohammadia School of engineering (EMI) and member of the Laboratory of Electronics and Communication (EMI). He received his Ph.D. in electronics of the Claude Bernard University in Lyon, He is a professor in Electronic and Communication Technology at the Department of Electrical Engineering in Mohammadia School of engineering in Rabat.

Author ID: 57201156464

Register for an ORCID ID:

https://orcid.org/register

Copyright (C) 2019 by author(s) and VsI Entrepreneurship and Sustainability Center

This work is licensed under the Creative Commons Attribution International License (CC BY).

http://creativecommons.org/licenses/by/4.0/

(c) (i) Open Access 